\title{
Effect of volatility of foreign direct investment inflows on corporate income tax revenue volatility
}

\section{4}

Received 16 April 2020 Revised 21 August 2020 23 October 2020 Accepted 28 October 2020

\author{
Sena Kimm Gnangnon \\ World Trade Organization, Geneva, Switzerland
}

\begin{abstract}
Purpose - This paper aims to examine how the volatility of foreign direct investment (FDI) inflows affects the volatility of corporate income tax revenue.

Design/methodology/approach - The study has used an unbalanced panel data set of 129 countries over the period 1981-2016 and the two-step system generalized methods of moment approach to perform the empirical analysis.

Findings - The main findings are that FDI volatility enhances the volatility of corporate income tax revenue in less advanced economies, but reduces it in relatively advanced countries. The positive corporate income tax revenue volatility effect of FDI inflows is far higher in non-tax haven countries than in tax haven countries. Additionally, FDI volatility exerts a higher positive effect on corporate income tax revenue volatility as countries experience greater dependence on natural resources. Finally, the positive effect of FDI volatility on corporate income tax revenue volatility is further amplified by higher FDI volatility.
\end{abstract}

Research limitations/implications - One important limitation of the present analysis is the use of aggregate FDI inflows because of the lack of data over a long period on greenfield FDI inflows and crossborder mergers and acquisitions FDI inflows. Therefore, an avenue for future research could be to explore separately the effect of the volatility greenfield FDI inflows and the volatility of cross-border mergers and acquisitions FDI inflows on the volatility of corporate income tax revenue, when long-time series data (covering many countries) would be available.

Practical implications - These outcomes particularly shed light on the role of FDI volatility on the volatility of corporate income tax revenue, particularly in countries that are highly dependent on natural resources. Foreign capital flows, notably FDI flows, play an essential role for countries' economic development through, inter alia, technology transfer, jobs creation and economic growth. Policymakers should aim to attract FDI, while also reducing their volatility, by designing and implementing policies and measures (such as those in favor of business environment improvement, property rights enforcement and political stability) that would assure foreign investors of the continuous high returns of their investments.

Originality/value - To the best of the author's knowledge, this is the first time this topic is being addressed empirically in the literature.

Keywords Corporate income tax revenue volatility, FDI volatility

Paper type Research paper

(c) Sena Kimm Gnangnon. Published in Applied Economic Analysis. Published by Emerald Publishing Limited. This article is published under the Creative Commons Attribution (CC BY 4.0) licence. Anyone may reproduce, distribute, translate and create derivative works of this article (for both commercial and non-commercial purposes), subject to full attribution to the original publication and authors. The full terms of this licence maybe seen at http://creativecommons.org/licences/by/4.0/legalcode

JEL classification - F2, H1, H2

This article represents the personal opinions of individual staff members and is not meant to represent the position or opinions of the WTO or its Members. The Author expresses gratitude to the two anonymous Reviewers for their very constructive comments that help improve the quality of the paper. Any errors or omissions are the fault of the Author.
Applied Economic Analysis Vol. 29 No. 86, 2021 pp. $124-151$

Emerald Publishing Limited 2632-7627

DOI 10.1108/AEA-04-2020-0030 


\section{Introduction}

Much work has been performed on the effect of foreign direct investment (FDI) on hostcountries' economic growth and development. In particular, some studies have explored the effect of FDI inflows on public revenue (Aslam, 2015; Bayar and Ozturk, 2018; Camara, 2019; Gnangnon, 2017; Okey and Nézan, 2013; Raff and Srinivasan, 1998), and notably on corporate income tax revenue (Gnangnon, 2017; Gropp and Kostial, 2000, 2001; Janský and Palanský, 2019; Nguyen et al., 2014). However, to the best of our knowledge, the effect of FDI volatility on corporate tax revenue volatility has not been investigated in the literature, even though some studies have been conducted on the macroeconomic effect of FDI volatility (Lensink and Morrissey, 2006). The present paper aims to fill this gap in the literature by investigating the effect of the volatility of FDI inflows on corporate income tax revenue volatility. Addressing this topic is all the more relevant that FDI volatility is closely related to economic growth and development. For example, Choong and Liew (2009) and Lensink and Morrissey (2006) have reported that FDI volatility has exerted a negative effect on economic growth. In contrast, Bairagi (2017) has uncovered that the positive conditional volatility of FDI (because of innovative shocks or policy innovations) has positively affected economic growth and development in the Indian subcontinent. On another note, the instability of tax revenue, including of corporate income tax revenue can be associated with public expenditure volatility (Bleaney et al., 1995; Ebeke and Ehrhart, 2012), which could in turn be detrimental to economic growth (Afonso and Furceri, 2010; Afonso and Jalles, 2012; Gong and Zou, 2002).

The analysis concerning the effect of FDI inflows volatility on corporate income tax revenue volatility has been performed using a panel data set of 129 countries (including both developed and developing countries) over the period 1981-2016. Results based on the twostep system generalized methods of moment (GMM) approach, have indicated that FDI volatility induces a higher volatility of corporate income tax revenue, with less advanced economies experiencing a higher corporate income tax revenue volatility effect of FDI volatility than do relatively more advanced countries. Moreover, we obtain that FDI volatility is associated with an increase in the volatility of corporate income tax revenue in countries that experience a greater dependence on natural resource rents.

The rest of the paper is structured as follows. Section 2 discusses how FDI volatility can influence corporate tax revenue volatility. Section 3 presents the model that helps investigate the issue under analysis. Section 4 discusses the appropriate econometric approach to estimate this model. Section 5 interprets empirical outcomes. Section 6 concludes the paper.

\section{Discussion on the effect of foreign direct investment volatility on corporate tax revenue volatility}

The effect of the volatility of FDI inflows on corporate income tax revenue volatility may not be straightforward. On the one hand, as FDI inflows can enlarge corporate income tax base through the entry of new firms or a rise in new investments by foreign investors (Gnangnon, 2017; Gropp and Kostial, 2000, 2001; Nguyen et al., 2014), one can expect variability in FDI inflows to induce an instability of the corporate income tax base, and hence corporate income tax revenue volatility. In particular, volatility in FDI inflows would translate into the volatility of multinational firms' profits in the host country, and in turn, lead to a rise in the volatility of corporate income tax revenue. Meanwhile, in many developing countries, foreign investors are granted many tax incentives [e.g. free economic zones in which goods are in general exempt from duties and taxes, and where corporate taxes are low or zero - see Zee et al. (2002) and Fuest and Riedel (2009)]. This is particularly the case for countries that 
AEA

29,86

are highly dependent on natural resources (Gajigo et al., 2012). As a result, FDI inflows volatility might not significantly affect corporate income tax revenue volatility. Furthermore, in light of the positive effect of FDI flows on local firms, including through backward and forward linkages (Alguacil et al., 2011; De Mello Jr, 1997; Figlio and Blonigen, 2000; Konara and Wei, 2017), one can expect that FDI inflows volatility would translate not only into the volatility of multinational firms' profits, but also into the volatility of domestic firms' profits. These two effects would, together, enhance the volatility of corporate income tax revenue. Finally, multinational firms could also engage in significant profit-shifting activities, including through the channels of debt shifting (Fuest et al., 2011; Huizinga and Laeven, 2008), the location of intangible assets (Bryan et al., 2017; Seabrooke and Wigan, 2015; Taylor et al., 2015) and strategic transfer pricing (Davies et al., 2018a; OECD, 2017; Peralta et al., 2006). As a result, we can also expect that the volatility of FDI inflows in the host-country may induce a significant variability of corporate income tax revenue. This is particularly because of the fact that profit-shifting can lead to significant tax revenue losses, including corporate tax revenue losses (Janský and Palanský, 2019). Summing-up this discussion, we can expect FDI inflows volatility to lead to a higher volatility of corporate income tax revenue volatility, with this effect being higher in less advanced economies (such as developing countries) than in relatively advanced countries (such as more developed countries).

On the other hand, we would like to note that the present analysis has used data on aggregate FDI inflows, collected from the database of the United Nations Conference on Trade and Development (UNCTAD). The data set on aggregate FDI inflows includes not only the two main modes through which FDI inflows occur (i.e. greenfield FDI inflows and cross-border mergers and acquisitions) (Davies et al., 2018b), but also reinvestments of earnings and debt. Statistics have shown that the bulk of greenfield FDI is hosted by developing countries, while developed countries are recipients of the majority of FDI in the form of cross-border mergers and acquisitions (Davies et al., 2018b; Carril-Caccia and Pavlova, 2018). For example, according to Carril-Caccia and Pavlova (2018), in 2016 [1], nearly 21,000 FDI projects took place, with a volume of almost US\$1.8tn. Out of these projects, 215 cross-border mergers and acquisitions deals accounted for $55 \%$ of the total volume.

While aggregate FDI flows can vary over time, this does not necessarily mean that the tax base, in particular the corporate income tax base, is consistently affected by ups and downs changes in FDI inflows. In fact, the variability of FDI inflows from one year to another year does not necessarily signify that the economic activity of multinationals is also volatile, and consequently that the corporate income tax base is volatile. Specially, a lower volume of FDI inflows might not result in the shrinking of the corporate income tax base. Additionally, some studies (Becker and Fuest, 2010; Hebous et al., 2011; Swenson, 2001) have shown that because host country taxes are capitalized in acquisition prices, greenfield FDI is more sensitive to taxes than FDI in the form of cross-border mergers and acquisitions. Mutti and Gruber (2004) have also shown empirically that foreign operations by multinationals of the USA geared toward export markets, rather than the domestic market, are particularly sensitive to host country taxation. This sensitivity is not only higher in developing countries than developed countries, but it also increases over time. Along the same line, Shirodkar and Konara (2017, p. 117) have confirmed the possible negative effect of the tax rate in the host country on subsidiary profit. Incidentally, not all FDI inflows are the outcomes of the creation of a new subsidiary in the host country, and cross-border merger and acquisitions that a country receives does not necessarily affect targeted firms' economic activities and their tax payments. In a nutshell, FDI inflows are not a proxy for multinationals' economic 
activity through time, but could be used at best, as a proxy for the investment decisions of multinationals that start an economic activity.

If aggregate FDI inflows reflect much more large cross-border mergers and acquisitions transactions in value (than greenfield FDI), it is possible that the corporate income tax base would not experience significant variability further to changes in aggregate FDI inflows, as such changes would be driven by variations in cross-border mergers and acquisitions FDI rather than greenfield FDI inflows. In contrast, if changes in aggregate FDI inflows are mainly driven by changes in greenfield FDI inflows, then the corporate income tax base could be severely affected and experience a significant volatility. The relationship between FDI inflows and corporate income tax volatility would be particularly significant in the event of disinvestment (i.e. when FDI values become negative): for example, positive values of greenfield FDI inflows would clearly entail greater economic activity in the host country and definitely affect the corporate income tax base. In contrast, negative [2] greenfield FDI inflows would be associated with a decline in economic activity and induce a shrinking of the corporate income tax base.

Overall, we hypothesize here that changes in FDI inflows driven by variations in crossborder mergers and acquisitions might not induce greater corporate income tax revenue volatility, whereas changes in FDI inflows driven by significant ups and downs movements of greenfield FDI inflows (including from positive to negative values or vice versa) would likely trigger significant volatility of corporate income tax revenue. As we will see later, the empirical analysis in the present paper covers the period 1981-2016. Unfortunately, the available data set on cross-border mergers and acquisitions FDI starts from 2000s, and therefore, prevents us from separating the effect of greenfield FDI inflows from that of crossborder mergers and acquisitions FDI inflows on corporate income tax revenue volatility, if we were to carry out the study over the period 1981-2016. Therefore, one limit of the paper is the use of aggregate FDI inflows, which includes not only greenfield FDI and cross-border mergers and acquisitions FDI, but also debt and reinvestments of earnings.

On another note, we can hypothesize that countries that are highly endowed with natural resources (endowment in natural resources is measured by the share of total natural resource rents in gross domestic product [GDP] of the FDI's host-country) would likely experience a higher volatility of corporate income tax revenue than countries relatively less endowed with natural resources [3]. This is because the latter countries do not have the administrative capacity to control the profit-shifting activities of multinational firms, and this can exacerbate the instability of corporate income tax revenue.

\section{Empirical model}

Building on the studies that have examined the determinants of tax revenue instability (Gnangnon, 2020; Gnangnon and Brun, 2019; Bleaney et al., 1995; Ebeke, 2014; Ebeke and Ehrhart, 2012; Lim, 1983), we postulate a model specification that includes in addition to the main variable of interest (i.e. the volatility of FDI inflows), other factors that can influence the effect of FDI inflows volatility on corporate income tax revenue volatility. These factors include the volatility of the economic growth rate, denoted "GRVOL"; trade openness, denoted "TROPEN"; financial openness, denoted "FINOPEN"; the institutional quality proxied by the level of democratization, denoted "POLITY2"; the inflation volatility, denoted "INFLVOL"; and the real per capita income, denoted "GDPC", which acts as a proxy for the development level. The computation of each of these variables is described in Appendix 1.

In light of the foregoing, we consider the following model:
Volatility of foreign direct investment 
AEA

29,86

$$
\begin{aligned}
\log \left({\text { CTAXVOL })_{i t}=}\right. & \alpha_{0}+\alpha_{1} \log (\mathrm{CTAXVOL})_{i t-1} \\
& +\alpha_{2} \log (\mathrm{FDIVOL})_{i t}+\alpha_{3} \log (\mathrm{GRVOL})_{i t}+\alpha_{4} \log (\mathrm{TROPEN})_{i t} \\
& +\alpha_{5} \mathrm{FINOPEN}_{i t}+\alpha_{6} \mathrm{POLITY}_{i t}+\alpha_{7} \log (\mathrm{INFLVOL})_{i t} \\
& +\alpha_{8} \log (\mathrm{GDPC})_{i t}+\gamma_{t}+\mu_{i}+\omega_{i t}
\end{aligned}
$$

The subscripts $i$ and $t$ represent, respectively, a country and the time-period. The model is estimated using an unbalanced panel data set of 129 countries (comprising both developed and developing countries - see Appendix 2) over the period 1981-2016. Non-overlapping sub-periods of five years (1981-1985, 1986-1990, 1991-1995, 1996-2000, 2001-2005, 2006-2010 and 2011-2016) have been used in the analysis. Thus, the volatility variables have been computed over these sub-periods (see Appendix 1), and the average of the other variables have been calculated over these sub-periods. The dependent variable "CTAXVOL" is the indicator of the volatility of the total corporate income tax revenue. It has been computed as the standard deviation of annual growth rate of the total corporate income tax revenue, expressed as a share of GDP, over non-overlapping sub-periods of five year. The variable "FDIVOL" is the main variable of interest in the analysis. It is primarily measured by the volatility of the real FDI inflows (constant US $\$ 2010$ prices), which is denoted "FDICSTVOL." For robustness check, we have alternatively measured this variable by the volatility of FDI (\% GDP). This volatility variable is denoted "FDIGDPVOL." We have applied the natural logarithm to all variables (except "FINOPEN" and "POLITY2") so as to reduce their high skewness.

$\alpha_{0}-\alpha_{8}$ are coefficients to be estimated; $\mu_{i}$ are countries' time invariant specific effects; and $\omega_{i t}$ is an idiosyncratic error-term. $\gamma_{t}$ are period dummies, and represent global shocks that affect countries' corporate tax revenue instability. The descriptive statistics associated with all variables used in model (1) are provided in Appendix 3.

We expect countries with a higher development level to have greater administrative capacity to manage and reduce corporate income tax revenue instability, than can do countries with a lower development level. Similarly, we expect a rise in economic growth volatility and inflation volatility to be associated with higher corporate income tax revenue instability. Incidentally, Ehrhart (2011) has underlined how good institutional quality can help induce foreign investors to comply with their tax revenue obligations. The provision of many tax incentives to promote FDI inflows results in higher corruption and business opportunities that induce socially unsuccessful profits (Zee et al., 2002). These might ultimately result in changes in corporate income tax revenue; in particular as in such a case, tax incentives would reduce corporate income tax revenue. We expect an improvement in the institutional quality to be associated with a lower instability of corporate income tax revenue. It is important to underline that our proxy for the institutional quality is the level of democracy [4] based on competitiveness of political participation, the openness and competitiveness of executive recruitment and constraints on the chief executive (denoted "POLITY2") (see Appendix 1 for more details on this indicator, which is extracted from the Polity IV Database, Marshall et al., 2018).

Concerning the corporate income tax revenue volatility effect of trade openness, we argue that it can translate through macroeconomic outcomes, including aggregate income, consumption, employment, salaries and prices (Ahmed and Suardi, 2009; di Giovanni and Levchenko, 2009; Kim et al., 2016). For example, greater trade openness can reduce output volatility by enhancing sectoral specialization (Calderon et al., 2006), 
while it can also affect positively economic growth volatility (di Giovanni and Levchenko, 2009; Kose et al., 2006; Mireku et al., 2017; Razin et al., 2003). On another note, greater financial openness (i.e. capital account liberalization) is associated with higher risk sharing, and hence with a lower economic growth volatility (Bekaert et al., 2006; Calderon et al., 2005; Haddad et al., 2013). Financial openness may also result in sudden stops, capital flight and ultimately in crises and a collapse in domestic production (Mendoza, 1991; Calvo and Mendoza, 1996; Arellano and Mendoza, 2002). In the same vein, Meller (2013) has found that financial openness decreases output foreign direct investment volatility in countries with low financial risk, but induces a high volatility of output in countries with a high financial risk.

Figures 1-3 display the developments of FDI volatility indicators (using each of the indicators of FDI volatility) and corporate income tax revenue volatility, respectively, over the full sample, the sub-sample of high-income countries (HICs) and the sub-sample of other countries in the full sample, denoted non-HICs that we consider here as "developing countries." The selection of these two groups of countries is based on the World Bank's classification of countries. We observe across these three figures that the two FDI volatility indicators are strongly correlated. Not only have these two indicators tightly evolved, but they have also moved in the same direction with the indicator of corporate income tax revenue volatility. After an upward movement between 1981-1985 and 1991-1995, the indicators have progressively declined to reach their lowest values at the end of the period (i.e. 2011-2016). Similar patterns are observed for the sub-sample of developing countries. However, for HICs, the indicator of corporate income tax revenue volatility has moved in an opposite direction to the two indicators of FDI volatility. Specially, the latter have experienced ups and downs movements between 1981-1985 and 1996-2000, and have since then being on a rising trend, and reached their highest values in 2011-2016. At the same time, corporate income tax revenue volatility has been declining, particularly between 2006-2010 and 2011-2016.

Figures 4 and 5 present the correlation pattern between FDI volatility (using each of the indicators of FDI volatility) and corporate income tax revenue volatility,

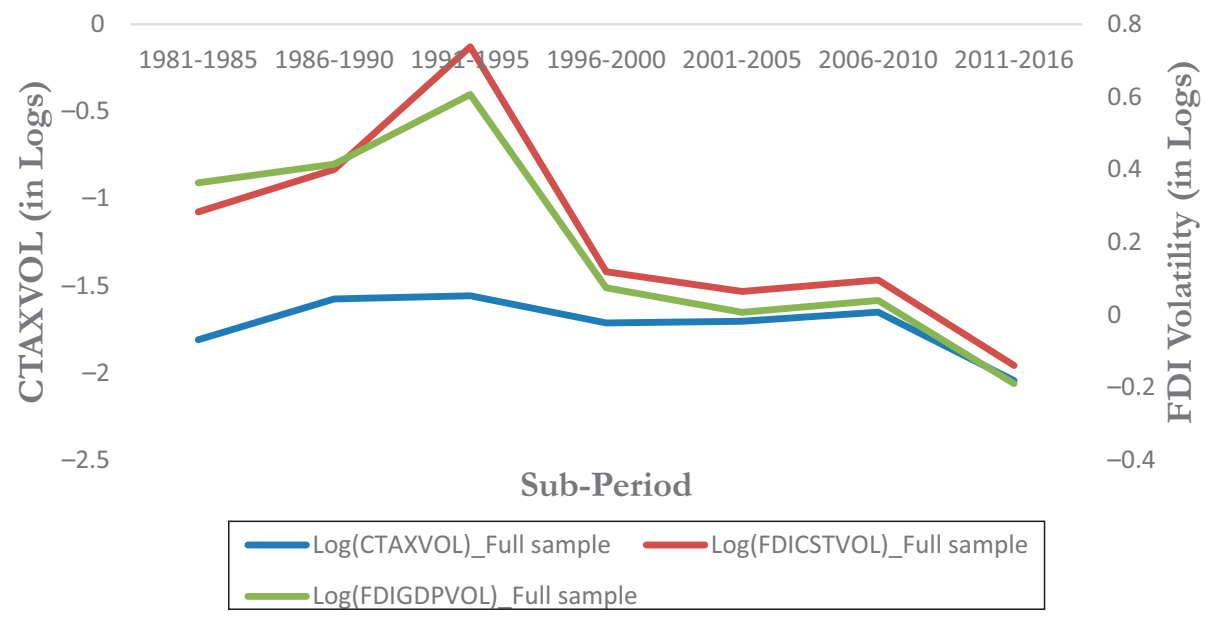

Source: Author

Figure 1.

Evolution of FDI volatility and corporate tax revenue volatility over the full sample 
0

1981-1985 1986-1990 1991-1995 1996-2000 2001-2005 2006-2010 2011-2016

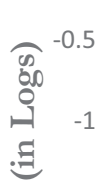

130

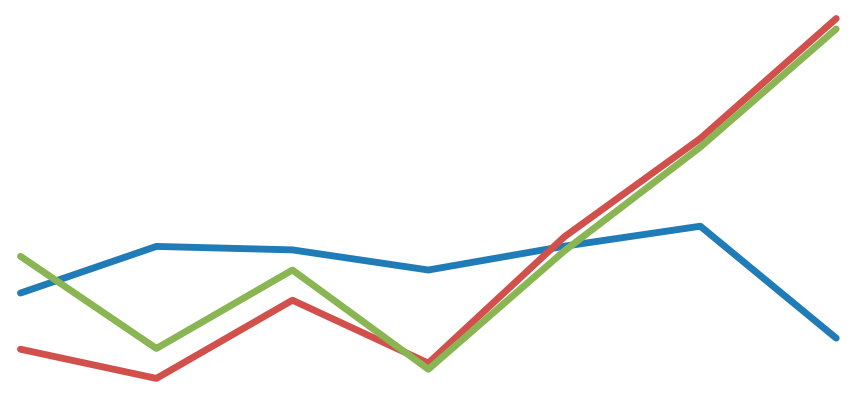

Evolution of FDI volatility and corporate tax revenue volatility over the sub-sample of HICs

\section{Figure 3.}

Evolution of FDI volatility and corporate tax revenue volatility over the sub-sample of nonHICs (i.e. developing countries)
Sub-Period

$-3$

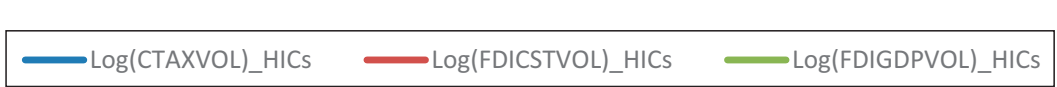

Source: Author

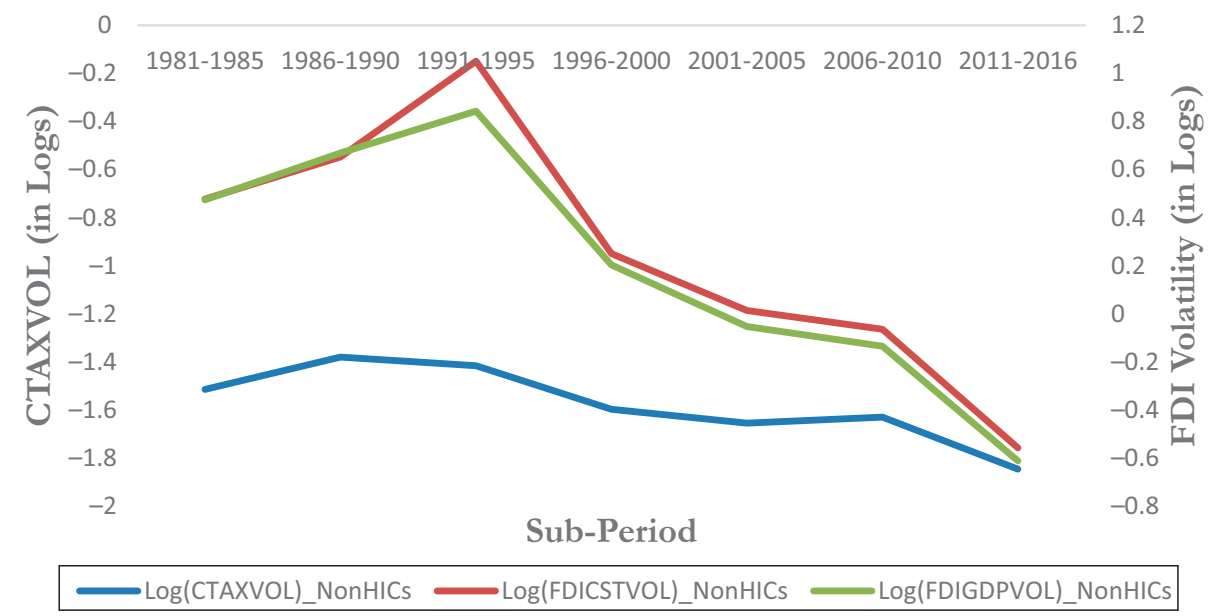

Source: Author

respectively, over the full sample (Figure 4) and the sub-samples of HICs and non-HICs (Figure 5). Both figures clearly show the existence of a positive correlation between these two variables, although some outliers [in particular countries for which Log (CTAXVOL) $<=-0.4$ ] appear in the figures. Outlier countries include Czech Republic, Egypt, Arab Republic and Uzbekistan. We will take into account these outliers in the empirical analysis. 

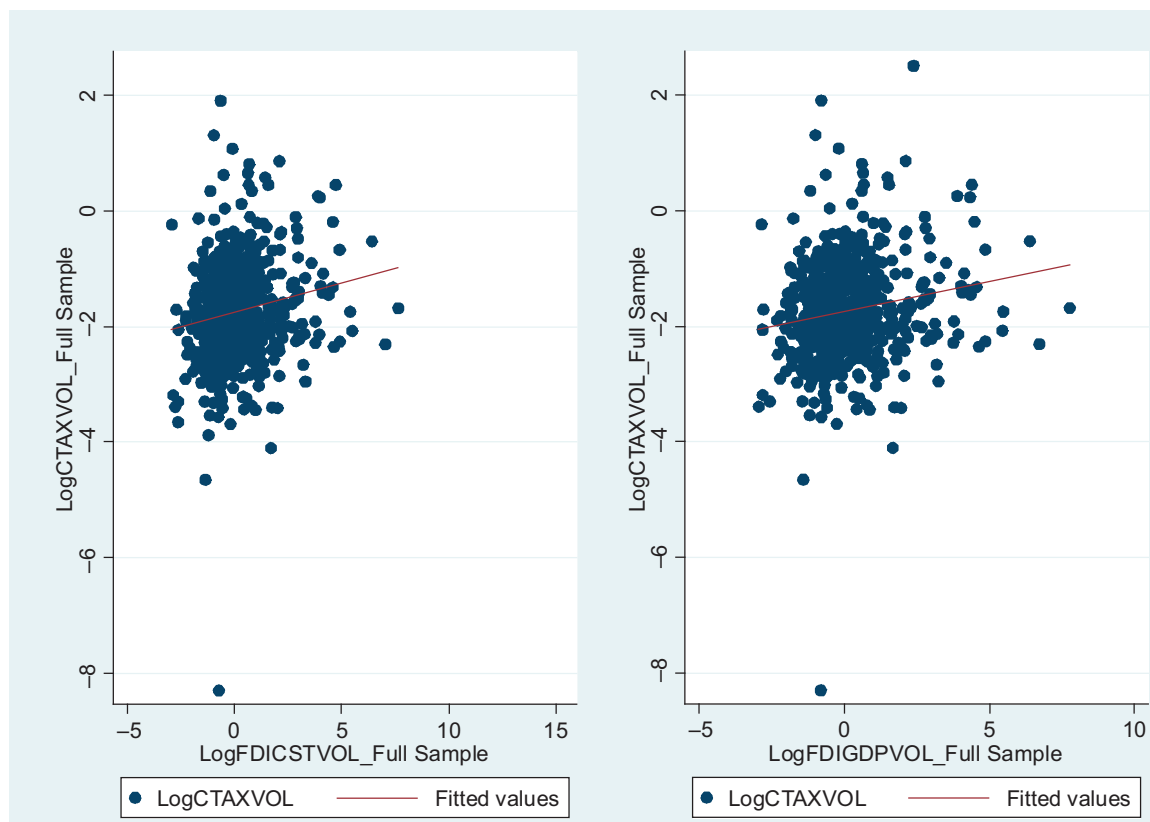

Volatility of
foreign direct
investment

131

Source: Author

\section{Estimation strategy}

In terms of estimation strategy, model (1) is estimated using the standard GMM approach proposed by Blundell and Bond (1998). This estimator is suitable for dynamic panel data set like ours, that is, with a small-time dimension and a large cross-section. Indeed, this estimator helps to solve several endogeneity concerns. The latter include the correlation between the one-period lag of the dependent variable and countries' specific time invariant effects [the so-called Nickell bias (Nickell, 1981) if the model were to be estimated using for example the within fixed effects]. Another endogeneity problem being dealt with by the GMM approach is the bi-directional causality between the dependent variable and many regressors, including the volatility of FDI inflows, the economic growth volatility, trade openness, financial openness and the institutional quality. For example, the reverse causality from the dependent variable to the FDI inflows volatility can arise from the fact that countries that experience higher volatility of corporate income tax revenue may be willing to implement policies that would reduce such volatility, and these policies might entail the mitigation of the volatility of FDI inflows [5]. These policies can also involve reducing trade openness and financial openness degrees if the latter are associated with a greater exposure of the country to high degrees of external shocks. Finally, as institutional quality can be associated with lower instability of total tax revenue (Gnangnon, 2020), and eventually lower instability of corporate income tax revenue, then one can also expect governments to improve the quality of their institutions so as to reach this objective. In light of these, in the regressions based on the two-step system GMM estimator, we treat as endogenous the variables measuring the volatility of FDI inflows, economic growth 
Figure 5.

Correlation pattern between FDI volatility and corporate tax revenue volatility over subsamples
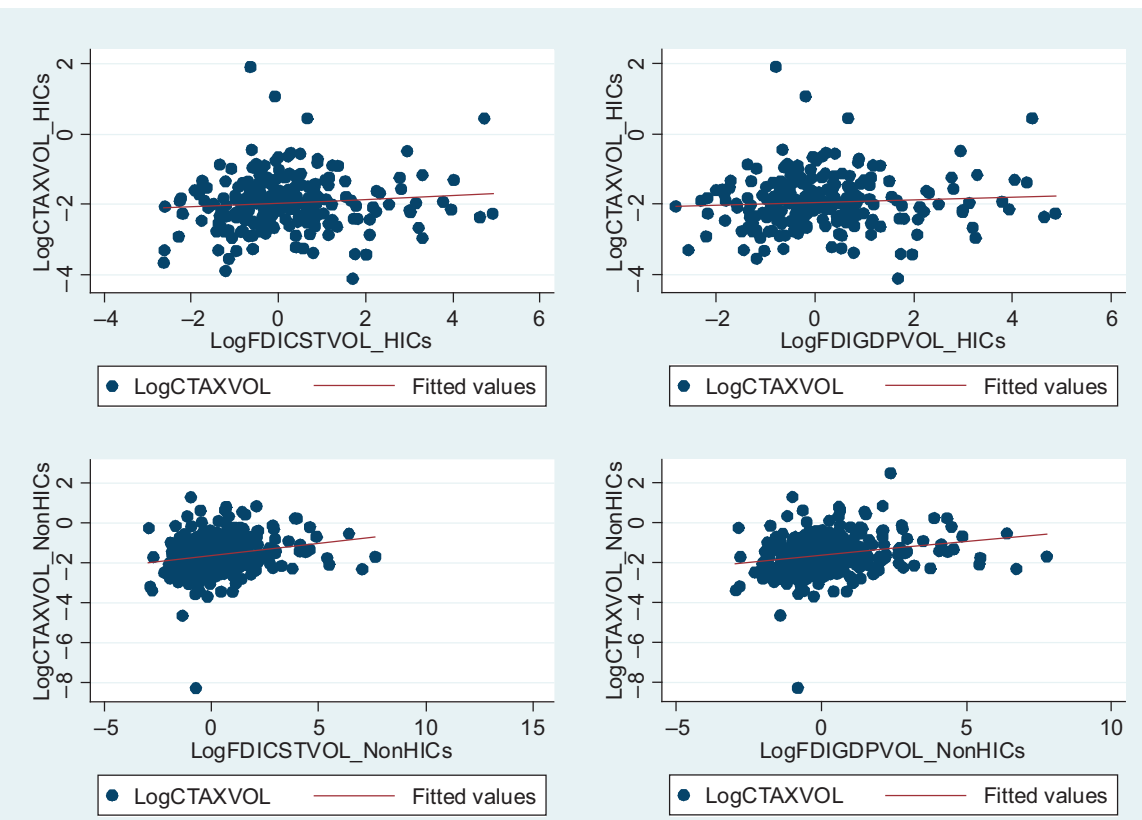

Source: Author

volatility, trade openness, financial openness and institutional quality. The use of this estimator entails the estimation of a system of equations, where an equation in differences is combined with an equation in levels, and where lagged first differences are used as instruments for the levels equation, and lagged levels are used as instruments for the firstdifference equation. The regressions have used a maximum of three lags of dependent variable as instruments, and three lags of endogenous variables as instruments. The consistency of the two-step system GMM estimator is assessed by performing three diagnostic tests. These include the Arellano-Bond test of first-order serial correlation (AR[1]) in the error term; the Arellano-Bond test of no second-order autocorrelation (AR[2]) in the error term; and the standard Sargan-Hansen test of over-identifying restrictions (OID), which determines the validity of the instruments used in the regressions. Furthermore, we report the number of instruments used in the regressions, given that a higher number of instruments than the number of countries may make the diagnostic tests less powerful (Roodman, 2009).

Even though the two-step system GMM approach is our primary estimator, we nevertheless present the outcomes of the estimation of model (1) (without the one-period lag of the dependent variable - but only with "FDICSTVOL" as a measure of FDI volatility) using standard econometric estimators, namely, the fixed effects and the feasible generalized least squares estimators. The outcomes of these estimations are presented in Table 1, even though they will likely be biased in light of the endogeneity concerns highlighted above. Nevertheless, such results can be useful for the sake of comparison with those obtained when using the two-step system GMM estimator. 


\begin{tabular}{|c|c|c|c|}
\hline Variables & $\begin{array}{c}\mathrm{FE} \\
\log (\mathrm{CTAXVOL}) \\
(1)\end{array}$ & $\begin{array}{c}\text { FGLS } \\
\log (\text { CTAXVOL) } \\
(2)\end{array}$ & $\begin{array}{l}\text { foratility of } \\
\text { investment }\end{array}$ \\
\hline Log(FDICSTVOL) & $0.0337(0.0257)$ & $0.0419 * * *(0.00745)$ & \\
\hline Log(GRVOL) & $0.146 * * *(0.0498)$ & $0.167 * * *(0.0220)$ & \\
\hline Log(TROPEN) & $-0.265(0.215)$ & $0.00532(0.0288)$ & \\
\hline FINOPEN & $-0.00132(0.00199)$ & $-0.000198(0.000391)$ & 133 \\
\hline POLITY2 & $0.00538(0.0126)$ & $-0.0131 * * *(0.00220)$ & \\
\hline Log(INFLVOL) & $0.0990 * * *(0.0376)$ & $0.137 * * *(0.0151)$ & \\
\hline Log(GDPC) & $0.00270(0.216)$ & $0.00609(0.0119)$ & \\
\hline Constant & $-1.051(1.822)$ & $-2.289 * * *(0.147)$ & \\
\hline Observations - countries & $621-129$ & $620-128$ & \\
\hline Within $R^{2}$ & 0.103 & & \\
\hline Between $R^{2}$ & 0.1026 & & \\
\hline Overall $R^{2}$ & 0.1234 & & \\
\hline Pseudo $R^{2}$ & & 0.4213 & Table 1. \\
\hline \multicolumn{3}{|c|}{$\begin{array}{l}\text { Notes: } * p \text {-value }<0.1 ; * * p \text {-value }<0.05 ; * * * p \text {-value }<0.01 \text {. Robust standard errors are in parenthesis. For } \\
\text { the fixed-effects based regression, standard errors have been clustered at the country-level. The Pseudo } R^{2} \\
\text { has been calculated for FGLS-based regression, as the correlation coefficient between the dependent } \\
\text { variable and its predicted values. Estimators: FE and FGLS with common AR(1) coefficient for all panels }\end{array}$} & $\begin{array}{r}\text { Effect of FDI } \\
\text { volatility on } \\
\text { corporate tax } \\
\text { revenue volatility }\end{array}$ \\
\hline
\end{tabular}

The empirical analysis based on the two-step system GMM estimator is conducted as follows. Column 1 of Table 2 reports the estimations' results of model (1), using "FDICSTVOL" as the measure of the variable "FDIVOL." Column 2 of the same table reports the estimates that allow examining whether the outlier countries identified above influence the outcomes reported in column 1 of Table 2 , in particular the results concerning the effect of FDI inflows volatility on corporate income tax revenue volatility. To that effect, we estimate a specification of model (1) in which we include a dummy variable, denoted "DUM" (which takes the value " 1 " for outlier countries, and "0" otherwise) as well as its interaction with the variable "FDICSTVOL." If the introduction of these two variables in the model leads to a significant change in the coefficient of the variable "FDICSTVOL" (both in terms of magnitude, sign and statistical significance), then the new specification of model (1) should definitely include these two variables. Otherwise, for the rest of the analysis, we can estimate model (1) as it stands, i.e. without taking explicitly into account the outliers, given that they do not influence the effect of FDI inflows volatility on corporate income tax revenue volatility. As we will see latter in the discussion of the empirical results, outliers do not significantly influence the effect of FDI volatility on corporate income tax revenue volatility. Column 3 of Table 2 reports the outcomes arising from the estimation of a variant of model (1) in which the variable "FDICSTVOL" is replaced with the variable "FDIGDPVOL," as a measure of "FDIVOL."

We report in columns 1 and 2 of Table 3 the outcomes of the estimation of two different other specifications of model (1) (i.e. with "FDICSTVOL" and "FDIGDPVOL" as the two different indicators of the dependent variable "FDIVOL") that allow investigating the effect of FDI volatility on corporate income tax revenue volatility in HICs vs developing countries. These results arise from the estimation of two specifications of model (1) that include the dummy "HIC" alongside its interaction with each of the variables "FDICSTVOL" and "FDIGDPVOL." This dummy represents HICs, and takes the value 1 when a country is considered by the World Bank as a HIC, and "0" otherwise. Likewise, columns 3 and 4 of Table 3 contain the outcomes of the estimation of two different other specifications of 


\section{4}

\begin{tabular}{lc}
\hline Variables & $\log (\mathrm{CTAXVOL})(1)$ \\
\hline Log(CTAXVOL) $t-1$ & $0.0758 * * *(0.0186)$ \\
Log(FDICSTVOL) & $0.113^{* * *}(0.0336)$ \\
DUM *[Log(FDICSTVOL)] & \\
DUM & \\
Log(FDIGDPVOL) & \\
Log(GRVOL) & $0.100 * *(0.0492)$ \\
Log(TROPEN) & $-0.540 * * *(0.0928)$ \\
FINOPEN & $0.00468 * * *(0.00141)$ \\
POLITY2 & $-0.0193 * * *(0.00733)$ \\
Log(INFLVOL) & $0.185 * * *(0.0299)$ \\
Log(GDPC) & $-0.130 * * *(0.0440)$ \\
Constant & $1.368 * * *(0.489)$ \\
Observations - countries & $498-129$ \\
Number of instruments & 95 \\
AR1 $(\phi$-value) & 0.0000 \\
AR2 $(p$-value) & 0.5334 \\
OID $(p$-value) & 0.4870
\end{tabular}

$\log (\mathrm{CTAXVOL})(2)$
0.0729 **** $(0.0208)$
0.0822 ** $(0.0335)$
$-0.0106(0.111)$
$-0.698 * *(0.285)$
$0.0501(0.0493)$
-0.468 *** $(0.0925)$
0.00426 *** $(0.00155)$
-0.0247 *** $(0.00761)$
0.174 *** $(0.0278)$
-0.136 *** $(0.0434)$
$1.210 * *(0.499)$
$498-129$
107
0.0000
0.4900
0.6224
Log(CTAXVOL) (3)
0.0813 **** (0.0192)
$0.129 * * *(0.0290)$
$0.0795 *(0.0435)$
$-0.468 * * *(0.0938)$
$0.00520 * * *(0.00132)$
$-0.0136 * *(0.00692)$
$0.177 * * *(0.0266)$
$-0.182 * * *(0.0377)$
1.441 *** $(0.413)$
$489-128$
95
0.0000
0.7105

0.4870

Notes: $* p$-value $<0.1 ; * * p$-value $<0.05 ; * * * p$-value $<0.01$. Robust standard errors are in parenthesis. In the two-step system GMM estimations, the variables "FDICSTVOL," "FDIGDPVOL," "GRVOL,"

Table 2.

Effect of FDI volatility on corporate tax revenue volatility
"TROPEN," "FINOPEN" and "POLITY2" have been considered as endogenous. Time dummies have been included in the regressions. The regressions have used three lags of the dependent variable as instruments, and three lags of endogenous variables as instruments. The variable "DUM" is a dummy variable representing outlier countries, and takes the value "1" for outlier countries (that is countries with [Log (CTAXVOL) $<=-0.4$ ), and "0" otherwise. Outlier countries are Czech Republic, Egypt, Arab Republic and Uzbekistan. Estimator: two-step system GMM

model (1) (i.e. with "FDICSTVOL" and "FDIGDPVOL" as the two different indicators of the dependent variable "FDIVOL") that allow assessing how the effect of FDI volatility on corporate income tax revenue volatility varies across countries. This analysis is performed by estimating specifications of model (1) that include the interaction between the variable "GDPC" with each of the variables "FDICSTVOL" and "FDIGDPVOL."

We present in columns 1 and 2 of Table 4 the outcomes arising from the estimation of two other specifications of model (1) (i.e. with "FDICSTVOL" and "FDIGDPVOL" as measures of the dependent variable "FDIVOL") that help investigate whether and if so, to what extent, the effect of FDI volatility on corporate income tax revenue volatility depends on countries' reliance on natural resources, measured by the share of natural resource rents in GDP. To that end, the two model specifications include the variable "RENTTOT" (in natural logarithm) (which measures the share of natural resource rents in GDP) as well as its interaction with each of the FDI volatility variables. Total natural resources rent ( $\%$ GDP) is the sum of oil rents ( $\%$ GDP), mineral rents ( $\%$ GDP), natural gas rents ( $\%$ GDP), coal rents ( $\%$ GDP) and forest rents ( $\%$ GDP). We expect the magnitude of the positive effect of FDI volatility on corporate income tax revenue volatility to increase as countries become increasingly dependent on natural resources.

Following Auty $(1997,2001)$ and Isham et al. (2005), we also decompose total natural resource rents into point source-type natural resource rents (denoted "POINTRENT"), and diffuse natural resources rents (denoted "DIFFUSERENT"). "Point source resources" are defined as those where ownership is concentrated and exploitation is capital intensive, and "Diffuse natural resources" include those where associated property rights are likely to be more widely dispersed across society and where investment barriers are more modest 


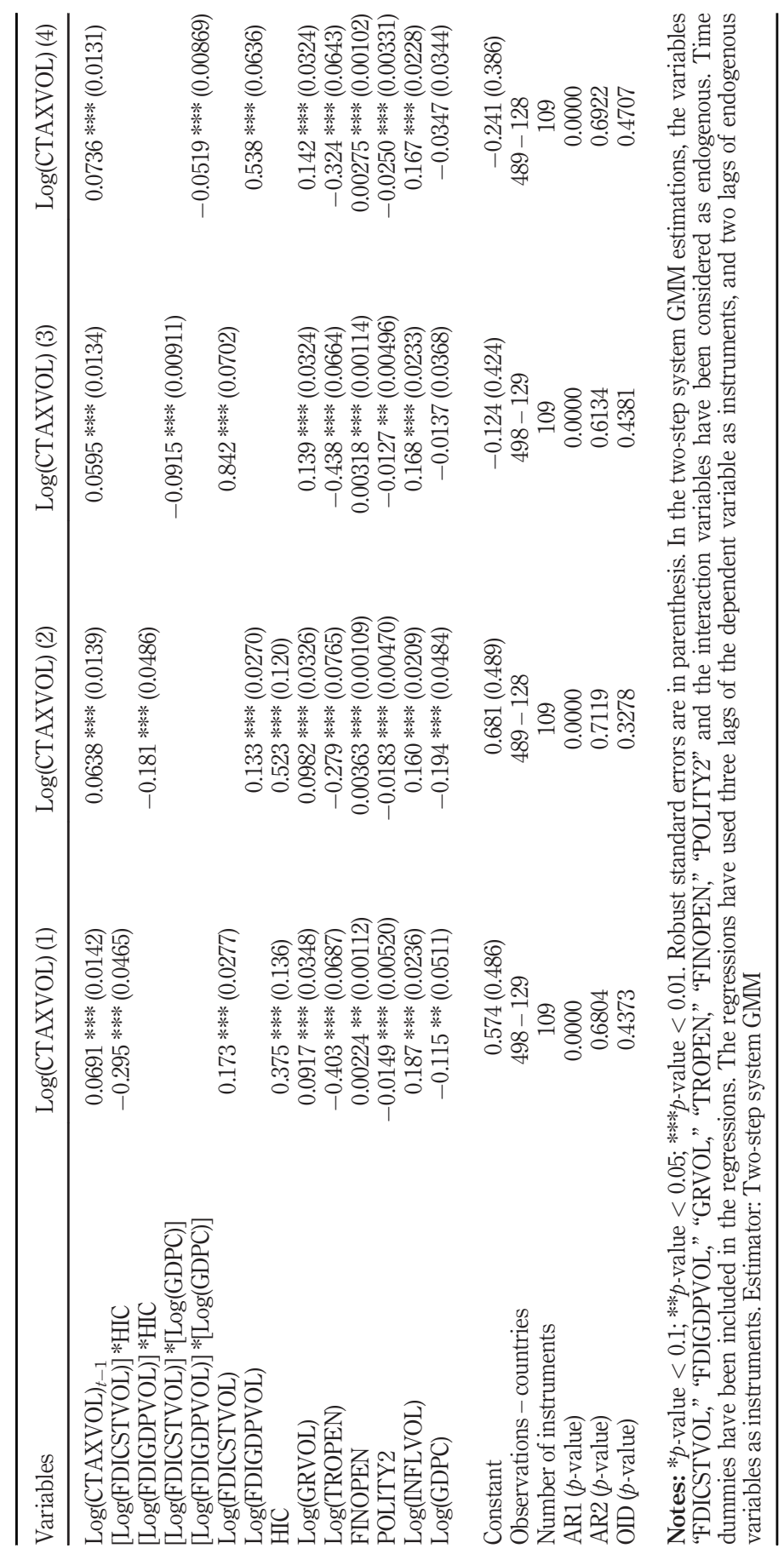

Volatility of foreign direct investment

135

Table 3. Effect of FDI volatility on corporate tax revenue volatility for varying development levels 
AEA

29,86

136

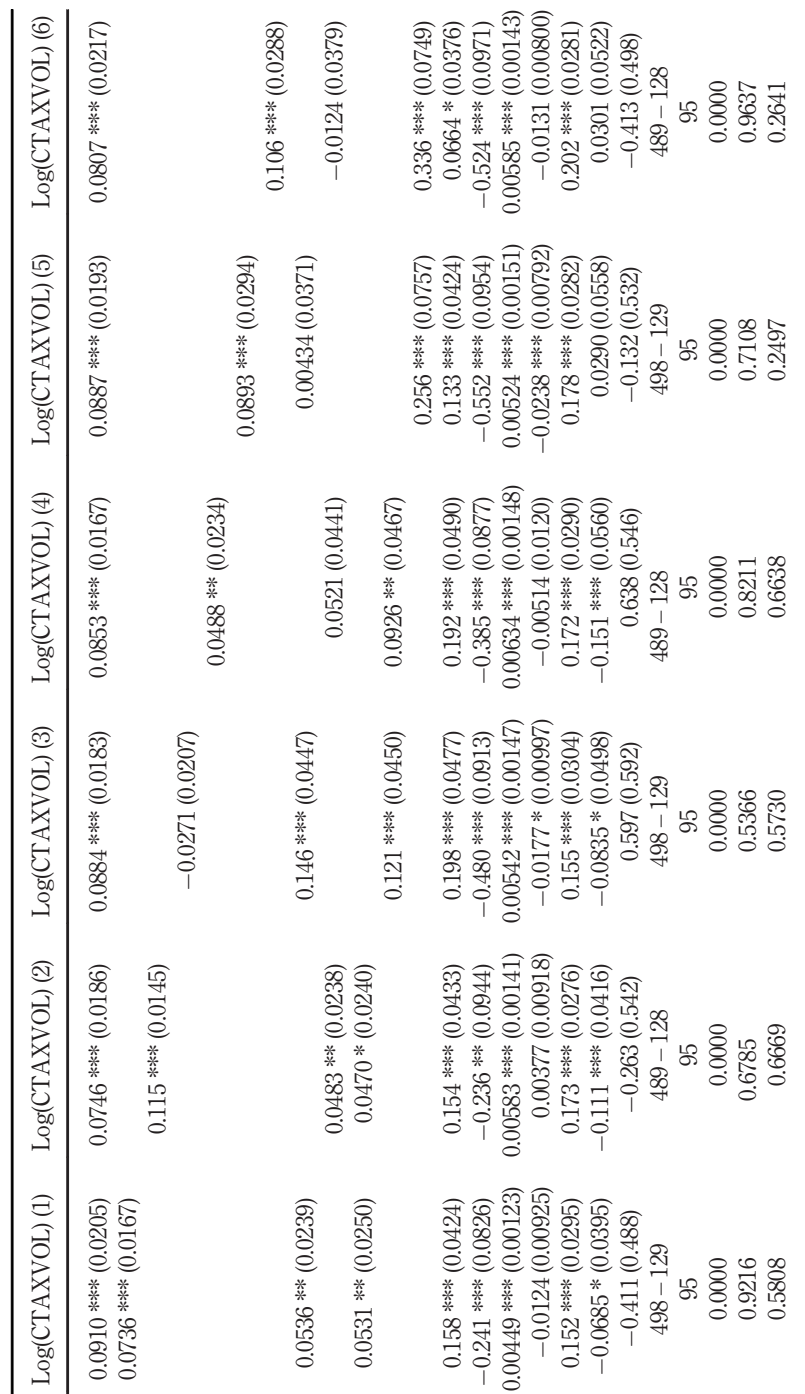

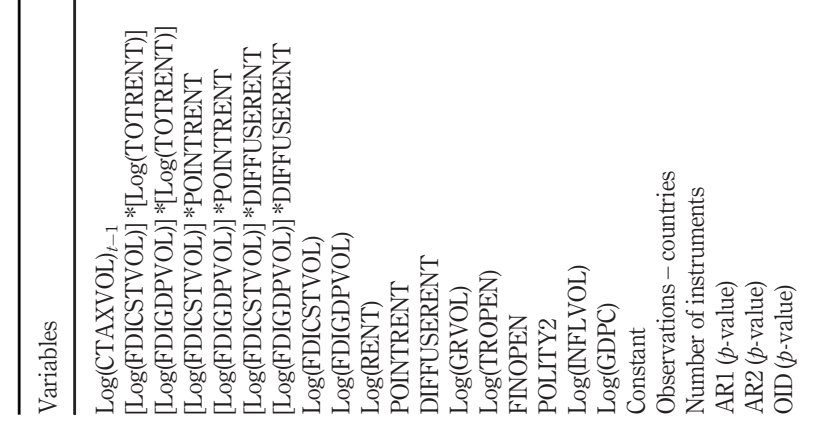

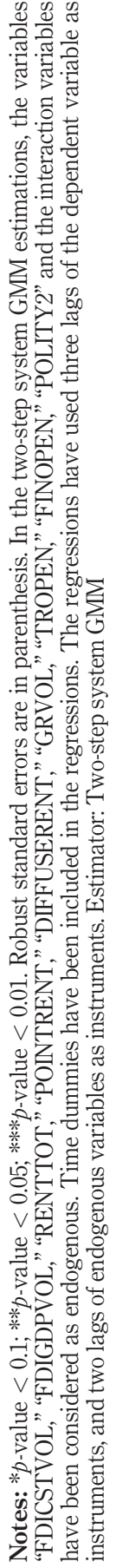

Table 4. Effect of FDI volatility on corporate tax revenue volatility for varying shares of natural resource rents in GDP 
(Stevens and Dietsche, 2008, p. 62). As oil, gas and mineral deposits can exhibit, to a greater or lesser extent, the attributes of point source resources (Stevens and Dietsche, 2008, p. 62), we compute the indicator "POINTRENT1" as the sum of oil rents (\% GDP), mineral rents $(\% \mathrm{GDP})$ and natural gas rents (\% GDP). As a result, the indicator "DIFFUSERENT1" has been computed as the sum of coal rents ( $\%$ GDP) and forest rents ( $\%$ GDP) [see also other studies such as Baldwin (1956), Bulte et al. (2005) and Mavrotas et al. (2011) for the distinction between point-source resources and diffuse natural resources]. We opt for this decomposition of total natural resource rents into point-resource rents and diffuse resourcerents because the literature has pointed out that the dependence on point-source-type natural resource hampers economic performance through its adverse effect on institutional development, including both governance and democracy (Bulte et al., 2005; Isham et al., 2005; Mavrotas et al., 2011). In contrast, these effects are much less strong in countries that are highly dependent on diffuse natural resources (i.e. for example, countries that rely primarily on livestock and agricultural produced by small family farms). Therefore, while we expect that FDI volatility could exert a higher positive effect on corporate income tax revenue volatility in both countries dependent on point-resource countries and countries dependent on diffuse natural resources, the magnitude of the effect for point-resource countries might be higher than that of diffuse natural resources dependent countries. As the indicators "POINTRENT1" and "DIFFUSERENT1" contain zero values, while concurrently displaying a high skewness, we have transformed each of them using the method proposed by Yeyati et al. (2007) (see Appendix 1 for further details). The transformed indicators are labeled "POINTRENT" and "DIFFUSERENT."

To examine empirically the extent to which the effect of FDI volatility on corporate tax revenue volatility depends on countries' reliance on point-resources, or diffuse resources, we estimate several variants of model (1) (i.e. with each of the two FDI volatility variables) in which we interact each of the variables "POINTRENT" and "DIFFUSERENT" with each of the FDI volatility variables. The outcomes of the estimation of these specifications of model (1) are contained in columns $4-6$ of Table 4 .

We present in Table 5 the outcomes of the estimation of the specification of model (1) that allows assessing whether the findings on the effect of FDI volatility on corporate tax revenue volatility are the same in tax haven countries vs other countries in the full sample. The list of tax haven countries in the full sample is obtained from Dharmapala and Hines (2009). Specifically, we have used the definition of tax haven based on Hines and Rice (1994) and Diamond and Diamond (2002). This list includes Bahrain, Cyprus, Ireland, Jordan, Liberia and Switzerland. To obtain outcomes reported in Table 5, we construct a dummy variable that takes the value " 1 " for countries included in this list (of tax haven countries) and " 0 " for the other countries of the full sample. This dummy is then interacted with each of the FDI volatility variables, and the resulting models are estimated using the two-step system GMM estimator.

Finally, we check whether there is a non-linear relationship between FDI volatility and corporate income tax revenue volatility by estimating another specification of model (1) that includes the squared term of the variable "FDIVOL," measured alternatively by "FDICSTVOL" and "FDIGDPVOL." Results of these estimations are presented in Table 6.

\section{Empirical outcomes}

Results in column 1 of Table 1 [estimates based on the "fixed effects (FEs)" approach] show no significant effect (at the conventional levels) of FDI volatility on the volatility of corporate income tax revenue. However, results in column 2 of the same table (those based on the feasible generalized least squares (FGLS) estimator) show a positive and significant effect
Volatility of foreign direct investment 


\begin{tabular}{|c|c|c|}
\hline Variables & Log(CTAXVOL) (1) & Log(CTAXVOL) (2) \\
\hline $\log (\text { CTAXVOL })_{t-1}$ & $0.0741 * * *(0.0184)$ & $0.0774 * * * *(0.0185)$ \\
\hline $\log ($ FDICSTVOL) & $0.133 * * *(0.0330)$ & \\
\hline$[\mathrm{Log}(\mathrm{FDICSTVOL})] * \mathrm{HAVEN}$ & $-0.116 * *(0.0593)$ & \\
\hline Log(FDIGDPVOL) & & $0.145 * * *(0.0277)$ \\
\hline$[\log ($ FDIGDPVOL) $] *$ HAVEN & & $-0.111 * *(0.0512)$ \\
\hline HAVEN & $0.0342(0.279)$ & $0.0258(0.232)$ \\
\hline Log(GRVOL) & $0.118 * * *(0.0410)$ & $0.0984 * * * *(0.0364)$ \\
\hline Log(TROPEN) & $-0.475 * * *(0.0912)$ & $-0.414 * * *(0.0935)$ \\
\hline FINOPEN & $0.00534 * * *(0.00135)$ & $0.00540 * * *(0.00127)$ \\
\hline POLITY2 & $-0.0176 * *(0.00736)$ & $-0.0102(0.00724)$ \\
\hline Log(INFLVOL) & $0.175 * * *(0.0274)$ & $0.174 * * *(0.0260)$ \\
\hline $\log (\mathrm{GDPC})$ & $-0.164 * * *(0.0420)$ & $-0.196 * * *(0.0392)$ \\
\hline Constant & $1.313 * * *(0.477)$ & $1.265 * * *(0.404)$ \\
\hline Observations - countries & $498-129$ & $489-128$ \\
\hline Number of instruments & 109 & 109 \\
\hline AR1 ( $\phi$-value) & 0.0000 & 0.0000 \\
\hline AR2 ( $p$-value) & 0.5343 & 0.6940 \\
\hline OID ( $p$-value) & 0.7892 & 0.8072 \\
\hline
\end{tabular}

Table 5.

Effect of FDI volatility on corporate tax revenue volatility in tax haven countries vs non-tax haven countries
Notes: $* p$-value $<0.1 ; * *$-value $<0.05 ; * * *$-value $<0.01$. Robust standard errors are in parenthesis. In the two-step system GMM estimations, the variables "FDICSTVOL," "FDIGDPVOL," "GRVOL," "TROPEN," "FINOPEN," "POLITY2" and the interaction variables have been considered as endogenous. Time dummies have been included in the regressions. The regressions have used three lags of the dependent variable as instruments, and two lags of endogenous variables as instruments. Estimator: Twostep system GMM
Table 6.

Effect of FDI volatility on corporate tax revenue volatility for varying degrees of FDI volatility

\begin{tabular}{|c|c|c|}
\hline Variables & Log(CTAXVOL) (1) & Log(CTAXVOL) (2) \\
\hline $\log (\text { CTAXVOL })_{t-1}$ & $0.0655 * * *(0.0159)$ & $0.0798 * * *(0.0145)$ \\
\hline Log(FDICSTVOL) & $0.0671 * *(0.0277)$ & \\
\hline$[\log (\text { FDICSTVOL })]^{2}$ & $0.0202 * * *(0.00468)$ & \\
\hline Log(FDIGDPVOL) & & $0.107 * * *(0.0310)$ \\
\hline$[\log (\mathrm{FDIGDPVOL})]^{2}$ & & $0.0173 * * *(0.00578)$ \\
\hline Log(GRVOL) & $0.0804 * * *(0.0268)$ & $0.0442(0.0269)$ \\
\hline Log(TROPEN) & $-0.534 * * *(0.0813)$ & $-0.552 * * *(0.0754)$ \\
\hline FINOPEN & $0.00396 * * *(0.00105)$ & $0.00573 * * *(0.000940)$ \\
\hline POLITY2 & $-0.0243 * * *(0.00403)$ & $-0.0237 * * *(0.00613)$ \\
\hline $\log (\mathrm{INFLVOL})$ & $0.177 * * *(0.0231)$ & $0.189 * * *(0.0199)$ \\
\hline $\log (\mathrm{GDPC})$ & $-0.0781 * * *(0.0288)$ & $-0.139 * * *(0.0299)$ \\
\hline Constant & $0.910 * *(0.383)$ & $1.431 * * *(0.304)$ \\
\hline Observations - countries & $498-129$ & $489-128$ \\
\hline Number of instruments & 109 & 109 \\
\hline AR1 ( $p$-value) & 0.0000 & 0.0000 \\
\hline AR2 ( $p$-value) & 0.5095 & 0.7315 \\
\hline OID ( $p$-value) & 0.6267 & 0.5931 \\
\hline
\end{tabular}

Notes: ${ }^{*} p$-value $<0.1 ; * * p$-value $<0.05$; ${ }^{* * *} p$-value $<0.01$. Robust standard errors are in parenthesis. In the two-step system GMM estimations, the variables "FDICSTVOL," "FDIGDPVOL," "GRVOL," "TROPEN," "FINOPEN," "POLITY2" and the interaction variables have been considered as endogenous. Time dummies have been included in the regressions. The regressions have used three lags of the dependent variable as instruments, and three lags of endogenous variables as instruments. Estimator: Twostep system GMM 
(at the $1 \%$ level) of FDI volatility on corporate income tax revenue volatility: a 1 percentage increase in FDI volatility is associated with a 0.04 percentage rise in corporate income tax revenue volatility. We note with respect to control variables that across the two columns, economic growth volatility and inflation volatility are positively associated with the volatility of corporate income tax revenue. The other control variables (with the exception of the institutional quality) do not significantly affect corporate income tax revenue volatility at the conventional levels. Results based on the FGLS approach show that the institutional quality appears to influence negatively and significantly corporate income tax revenue volatility, while for results based on the $\mathrm{FE}$ estimator, there is no significant effect of institutional quality on corporate income tax revenue volatility.

Turning to the two-step system GMM-based regressions (see Tables 2-6), we first note that across all columns of these tables, the requirements of the diagnostic tests of the twostep system GMM estimator are met. The coefficient of the one-period lag of the variable "CTAXVOL" is positive and significant at the $1 \%$ level, thereby validating the need for considering a dynamic model specification in the analysis. This also shows the persistence of the volatility of corporate income tax revenue over time. The nil hypotheses of the AR(1) and $\operatorname{AR}(2)$ tests are not rejected, which confirms the presence of the first-order serial correlation, and the absence of the second-order serial correlation. Finally, all $p$-values related to the OID test exceed 0.10 . Additionally, as expected, the number of instruments used in the regressions is lower than the number of countries used in the analysis. All these results suggest that the two-step system GMM estimator is appropriate for conducting the empirical analysis.

Estimates in columns 1 and 2 of Table 2 show that the coefficients of the variable "FDICSTVOL" are both statistically significant at the $1 \%$ level, and amount to 0.11 (in column 1) and 0.08 (in column 2). We conclude that when taking into account outliers in the regressions, the coefficient of the FDI volatility variable in column 2 is not significantly different from the one obtained in column 1 of the same table. Additionally, the interaction term related to the interaction variable "DUM* $[\mathrm{Log}(\mathrm{FDICSTVOL})]$ " is not significant at the conventional levels. In light of all these findings, we conclude that outlier countries do not influence the outcome reported in column 1 of Table 2 concerning the effect of FDI volatility on corporate income tax revenue volatility. Incidentally, the coefficient associated with the variable "FDICSTVOL" in column 1 of Table 2 is almost triple of the coefficient of the same variable in column 2 of Table 1 . This is likely because of the endogeneity of the FDI volatility variable, and hence, justifies the use of the two-step system GMM approach in the analysis to handle the endogeneity concerns.

Results in column 3 of Table 2 also indicate that the coefficient of the variable "FDIGDPVOL" is positive and significant at the $1 \%$ level. Interestingly, this coefficient, which amounts to 0.129 (i.e. 0.13), is quite similar to the coefficient reported in column 1 of Table 1 (which is 0.11 ). In terms of magnitude of the impacts, we obtain that a 1 percentage increase in FDI volatility (measured by the volatility of real FDI inflows) is associated with a 0.11 percentage rise in corporate income tax revenue volatility; and a 1 percentage increase in FDI volatility (measured by the volatility of the share of FDI inflows in GDP) is associated with a 0.13 percentage increase in corporate income tax revenue volatility. As for control variables, results in columns 1 and 3 are quite similar (as are also those in column 2 of Table 2). Specifically, corporate income tax revenue volatility is driven positively by higher economic growth volatility, greater financial openness and higher inflation volatility. In the meantime, greater trade openness, an improvement in the institutional quality and the rise in per capita income are associated with lower corporate income tax revenue volatility.
Volatility of foreign direct investment 
AEA

29,86

Results in columns 1 and 2 of Table 3 indicate that the interaction variables with the dummy "HIC" hold negative and significant coefficients at the $1 \%$ level. These suggest that FDI volatility exerts a higher effect in HICs than in developing countries. As the coefficients of the variables "[Log(FDICSTVOL)]" and "[Log(FDICSTVOL)]" are positive and significant at the $1 \%$ level, we deduce that the net effects of FDI volatility ("FDICSTVOL") on corporate tax revenue income volatility in HICs and developing countries amount, respectively, to $-0.122(=-0.295+0.173)$ and +0.173 . This signifies that in HICs, FDI volatility results in lower corporate tax revenue income volatility, while in developing countries, it induces a higher volatility of corporate tax revenue income. Specially, a 1 percentage increase in FDI volatility (measured by the volatility of real FDI inflows) induces a 0.12 percentage fall in corporate income tax revenue volatility in HICs; and a 1 percentage increase in FDI volatility (measured by the volatility of the share of FDI inflows in GDP) is associated with a 0.17 percentage increase in corporate income tax revenue volatility. Similarly, the net effects of FDI volatility (measured by the volatility of FDI in percentage of GDP) on corporate tax revenue income volatility in HICs and developing countries amount, respectively, to -0.05 $(=-0.181+0.133)$ and +0.133 . The above conclusion concerning the effect of FDI volatility ("FDICSTVOL") on corporate tax revenue income volatility in HICs and developing countries also applies here. The difference in outcomes between developed and developing countries could be attributed to the differences in the relevance of greenfield FDI inflows and cross-border mergers and acquisitions FDI inflows: as noted above, developing countries tend to attract the majority of greenfield FDI, while cross-border mergers and acquisitions FDI tends to be located in developed countries. Given the greater sensitivity of greenfield FDI inflows (compared to cross-border mergers and acquisitions FDI) to taxes in the host countries, it is likely that FDI volatility induce higher FDI volatility in developing countries, while eventually reducing it in developed countries.

Results in columns 3 and 4 of Table 3 confirm the findings in columns 1 and 2 of the same table. We note from the columns 3 and 4 that the interactions between each of the FDI volatility variables and the real per capita income hold negative and significant coefficients at the $1 \%$ level, while the FDI volatility variables have positive and significant coefficients at the $1 \%$ level. At least, these indicate that as countries develop, they experience a lower positive effect of FDI volatility on corporate income tax revenue volatility. We conclude that FDI volatility exerts a positive and significant effect on corporate income tax revenue volatility in countries whose real per capita income is lower than a certain threshold. For the other countries (i.e. those with a real per capita income higher than this threshold), FDI volatility is associated with lower corporate income tax revenue volatility. These thresholds amount to US\$9,918.8 [= exponential (0.842/0.0915)] for the regression-based on "FDICSTVOL" and US\$31,764 [= exponential (0.538/0.0519)] for the regression-based on "FDIGDPVOL." The key message from this analysis is that less advanced economies experience a positive effect of FDI volatility on corporate income tax revenue volatility, while in relatively advanced economies, FDI volatility is negatively associated with corporate income tax revenue volatility.

We note from columns 1 and 2 of Table 4 that the coefficients of the interaction variable between each of the FDI volatility variables and the total natural resource rents variable are positive and significant at the $1 \%$, while at the same time, the coefficient of each of the FDI volatility variables is significant at the $5 \%$ level. We, therefore, conclude that regardless of the indicator of FDI volatility used, countries that are dependent on natural resources experience a higher positive effect of FDI volatility on corporate income tax revenue volatility, and the higher this dependence on natural resources, the greater is the positive (enhancing) effect of FDI volatility on corporate income tax revenue volatility. Results in 
column 3 suggest that the interaction term of the variable "[Log(FDICSTVOL)] *POINTRENT" is not significant at the $10 \%$ level. This indicates that the effect of FDI volatility (measured by FDICSTVOL) on corporate income tax revenue volatility does not depend on countries' reliance on point-source natural resources. Meanwhile, the interaction term of the variable "[Log(FDIGDPVOL)]*POINTRENT" is significant at the $5 \%$ level. This reveals that in contrast with the previous finding that is based on the volatility of real values of FDI inflows, the volatility of FDI inflows (\% of GDP) on corporate income tax revenue volatility increases as the point-source resource rents rise. At the same time, the coefficients of "[Log(FDICSTVOL) ]*DIFFUSERENT" and "[Log(FDIGDPVOL)]*DIFFUSERENT" are statistically significant at the $1 \%$ level, whereas the coefficients of "Log(FDICSTVOL)" and "Log(FDIGDPVOL)" are not significant at the conventional levels. In light of these, we conclude that the effect of FDI volatility (irrespective of the way it is measured) on corporate income tax revenue volatility consistently increases as the dependence on diffuse-natural resources rises.

Taking up now the outcomes displayed in Table 5, we note that the coefficients of both "Log(FDICSTVOL)" and "Log(FDIGDPVOL)" are positively significant at the 1\% level, while the interaction terms related to the variables "[Log(FDICSTVOL)]*HAVEN" and "[Log(FDIGDPVOL)]*HAVEN" are both negative and significant at the 5\% level. These outcomes suggest that irrespective of the way it is measured, FDI volatility exerts a higher negative effect on corporate income tax revenue volatility in tax haven countries than in non-tax haven countries. The net effects of FDI volatility (measured by "FDICSTVOL") on corporate income tax revenue volatility in tax haven countries and non-tax haven countries amount, respectively, to $0.017(=-0.116+0.133)$ and 0.133 . It, therefore, appears that the magnitude of the positive effect of the volatility of real FDI on corporate income tax revenue volatility is far higher in non-tax haven countries than in tax haven countries. A 1 percentage increase in FDI volatility (i.e. the volatility of real FDI inflows) is associated with a 0.017 percentage increase in corporate income tax revenue volatility in tax haven countries; and a 0.13 percentage rise in corporate income tax revenue volatility in non-tax haven countries. The same reasoning applies to results obtained based on the volatility of FDI ( $\%$ GDP), with the net effects of FDI volatility on corporate income tax revenue volatility in tax haven countries and non-tax haven countries amounting, respectively, here to $0.034(=-0.111+0.145)$ and 0.145 .

Finally, the estimates presented in columns 1 and 2 of Table 6 (using, respectively, "FDICSTVOL" and "FDIGDPVOL" as measures of "FDIVOL") show positive and significant (at least at the $5 \%$ level) coefficients of the FDI volatility variables as well as the squared term of each these FDI volatility variables. In other words, there is a non-linear relationship between FDI volatility and corporate income tax revenue volatility, whereby the positive effect of FDI volatility on corporate income tax revenue volatility is further enhanced (amplified) by a higher volatility in FDI inflows.

Across Tables 3-6, results of control variables align, in general, with those presented in Table 2 , notably in column 1 and 3 of this table.

\section{Conclusion}

In this paper, we have investigated the effect of FDI volatility on corporate income tax revenue volatility, using an unbalanced panel data set of 129 countries over the period 1981-2016. The findings have indicated that FDI volatility tends to enhance corporate income tax revenue volatility in less advanced economies, but reduce it in relatively advanced countries. These suggest that relatively advanced economies are more able to manage the volatility of FDI inflows so as to ensure that it does not translate into higher
Volatility of foreign direct investment 
AEA 29,86

volatility of the corporate income tax revenue. Furthermore, and interestingly, the positive corporate income tax revenue volatility effect of FDI volatility rises as countries experience a higher dependence on total natural resources: this effect seems to be more evident for countries that are dependent on diffuse natural resources than for countries that are dependent on point-source resources. Furthermore, FDI volatility induces a lower positive effect on corporate income tax revenue volatility in tax haven countries than in non-tax haven countries. Finally, the positive corporate income tax revenue volatility effect of FDI volatility is further enhanced (amplified) by a higher volatility in FDI inflows.

These outcomes particularly shed light on the role of FDI volatility on the volatility of corporate income tax revenue, particularly in countries that are highly dependent on natural resources and non-tax haven countries. They show that one way for policymakers to enhance the stability of corporate tax revenue (given the positive economic growth effect of the latter) is to ensure a stability of FDI inflows. Foreign capital flows, notably FDI flows, play an essential role for countries' (including developing countries) economic development through, inter alia, technology transfer, jobs creation and economic growth. Thus, policymakers should aim to attract FDI, while also designing and implementing policies and measures (such as those in favor of business environment improvement, property rights enforcement and political stability) that would assure foreign investors - in particular those engaged in developing countries - of the continuous high returns of their investments. This would contribute to avoiding sudden reversals of FDI inflows or disinvestments by foreign firms that could trigger a high volatility of corporate income tax revenue in developing countries.

One important limitation of the present analysis is the use of aggregate FDI inflows because of the lack of data over a long period on greenfield FDI inflows and cross-border mergers and acquisitions FDI inflows. Therefore, an avenue for future research could be to explore separately the effect of the volatility of greenfield FDI inflows and the volatility of cross-border mergers and acquisitions FDI inflows on the volatility of corporate income tax revenue, when long-time series data (covering many countries) would be available. It might also be useful to explore in the future (when data would be available) how the volatility of FDI inflows in natural resources sectors influences corporate income tax revenue volatility, particularly in natural resource-dependent countries.

\section{Notes}

1. As it would be seen later in the analysis, 2016 is the last year of our panel data set.

2. It is worth noting that our data set on FDI inflows used to compute FDI volatility (see Section 2) contains many negative values of FDI inflows.

3. According to Boyce and Ndikumana (2003), the resource sector is the main source of illicit financial flows. Additionally, the size of the rents at stake, the asymmetry between highly capacitated foreign companies and the governments, combined with the weak governance and the lack of transparency in states, result in non-negligible tax evasion and corruption in resourcerich countries.

4. Numerous studies have also used the level of democratization in a country as a proxy for the institutional quality. These include, for example, Charron and Lapuente (2010), Desbordes and Verardi (2017), Guerin and Manzocchi (2009), Jensen (2003), Li and Resnick (2003), Oneal (1994), Rodrik (1996) and Sung (2004).

5. For example, improving the institutional quality such as ensuring better business environment and enhancing the enforcement of property rights could help avoid sudden reversals of FDI inflows, and hence help dampen FDI volatility. 


\section{References}

Afonso, A. and Furceri, D. (2010), "Government size, composition, volatility and economic growth", European Journal of Political Economy, Vol. 26 No. 4, pp. 517-532.

Afonso, A. and Jalles, J.T. (2012), "Fiscal volatility, financial crises and growth", Applied Economics Letters, Vol. 19 No. 18, pp. 1821-1826.

Ahmed, A.D. and Suardi, S. (2009), "Macroeconomic volatility, trade and financial liberalization in Africa", World Development, Vol. 37 No. 10, pp. 1623-1636.

Alguacil, M., Cuadros, A. and Orts, V. (2011), "Inward FDI and growth: the role of macroeconomic and institutional environment", Journal of Policy Modeling, Vol. 33 No. 3, pp. 481-496.

Arellano, C. and Mendoza, E.G. (2002), "Credit frictions and 'sudden stops' in small open economies: an equilibrium business cycle framework for emerging markets crises”, NBER Working Papers 8880, National Bureau of Economic Research, Cambridge, MA.

Aslam, M. (2015), "A case study of cointegration relationship between tax revenue and foreign direct investment: Evidence from Sri Lanka”, In 2nd International Symposium, FIA, South Eastern University of Sri Lanka, Vol. 241, p. 251.

Auty, R.M. (1997), "Natural resources, the state and development strategy", Journal of International Development, Vol. 9 No. 4, pp. 651-663.

Auty, R.M. (2001), "Introduction and overview”, In: Auty, R.M. (Ed.), Resource Abundance and Economic Development. OUP, Wider Studies in Development Economics, Oxford University Press.

Bairagi, R. (2017), "Impact of foreign direct investment volatility on economic development in the Indian subcontinent", The World Economy, Vol. 40 No. 12, pp. 2832-2853.

Baldwin, R. (1956), "Patterns of development in newly settled regions", The Manchester School, Vol. 24 No. 2,pp. 161-179.

Bayar, Y. and Ozturk, O.F. (2018), "Impact of foreign direct investment inflows on tax revenues in OECD countries: a panel cointegration and causality analysis", Theoretical and Applied Economics, XXV, No. 614, pp. 31-40.

Becker, J. and Fuest, C. (2010), "Taxing foreign profits with international mergers and acquisitions", International Economic Review, Vol. 51 No. 1, pp. 171-186.

Bekaert, G., Harvey, C.R. and Lundblad, C. (2006), "Growth volatility and financial liberalization”, Journal of International Money and Finance, Vol. 25 No. 3, pp. 370-403.

Bleaney, M., Gemmell, N. and Greenaway, D. (1995), "Tax revenue instability, with particular reference to Sub-Saharan Africa”, Journal of Development Studies, Vol. 31 No. 6, pp. 883-902.

Blundell, R. and Bond, S. (1998), "Initial conditions and moment restrictions in dynamic panel data models", Journal of Econometrics, Vol. 87 No. 1, pp. 115-143.

Boyce, J.K. and Ndikumana, L. (2003), "Public debts and private assets: explaining capital flight from Sub-Saharan African countries”, World Development, Vol. 31 No. 1, pp. 107-130.

Bryan, D., Rafferty, M. and Wigan, D. (2017), "Capital unchained: finance, intangible assets and the double life of capital in the offshore world", Review of International Political Economy, Vol. 24 No. 1, pp. 56-86.

Bulte, E.H., Damania, R. and Deacon, R. (2005), "Resource intensity, institutions, and development", World Development, Vol. 33 No. 7, pp. 1029-1044.

Calderon, C.A., Loayza, N.V. and Schmidt-Hebbel, K. (2005), "Does openness imply greater exposure?”, Policy Research Working Paper 3733, The World Bank, Washington, DC.

Calderon, C., Loayza, N., Schmidt-Hebbel, K. (2006), "External conditions and growth performance" Central Banking, Analysis, and Economic Policies Book Series, in: Ricardo Caballero and César Calderón and Luis Felipe Céspedes and Norman Loayza (Series Editor) and Klaus Sc (Ed.), External Vulnerability and Preventive Policies, edition 1, chapter 3, Central Bank of Chile, Vol. 10, pp. 41-70. 
AEA 29,86

Calvo, G. and Mendoza, E. (1996), "Mexico's balance of payments crises: a chronicle of a death foretold”, Journal of International Economics, Vol. 41 Nos 3/4, pp. 235-264.

Camara, A. (2019), "Long run effects of foreign direct investment on tax revenue in developing countries", University Clermont Auvergne, CNRS, IRD, CERDI, available at: https:/cerdi.uca.fr/ medias/fichier/camara-abdramane-fdi-tax_1560523703303-pdf

Carril-Caccia, F. and Pavlova, E. (2018), "Foreign direct investment and its drivers: a global and EU perspective", Economic Bulletin Articles, Vol. 4 available at: www.ecb.europa.eu/pub/economicbulletin/articles/2018/htm1/ecb.ebart201804_01.en.html

Charron, N. and Lapuente, V. (2010), "Does democracy produce quality of government?", European Journal of Political Research, Vol. 49 No. 4, pp. 443-470.

Chinn, M.D. and Ito, H. (2006), "What matters for financial development? Capital controls, institutions, and interactions", Journal of Development Economics, Vol. 81 No. 1, pp. 163-192.

Choong, C.-K. and Liew, V. K-S. (2009), "Impact of foreign direct investment volatility on economic growth of ASEAN-5 countries”, Economics Bulletin, Vol. 29 No. 3, pp. 1829-1841.

Davies, R.B., Desbordes, R. and Ray, A. (2018b), "Greenfield versus merger and acquisition FDI: Same wine, different bottles?”, Canadian Journal of Economics/Revue Canadienne D'économique, Vol. 51 No. 4, pp. 1151-1190.

Davies, R.B., Martin, J., Parenti, M. and Toubal, F. (2018a), "Knocking on tax haven's door: Multinational firms and transfer pricing", The Review of Economics and Statistics, Vol. 100 No. 1, pp. 120-134.

De Mello Jr, L.R. (1997), "Foreign direct investment in developing countries and growth: a selective survey", Journal of Development Studies, Vol. 34 No. 1, pp. 1-34.

Desbordes, R. and Verardi, V. (2017), "Foreign direct investment and democracy: a robust fixed effects approach to a complex relationship”, Pacific Economic Review, Vol. 22 No. 1, pp. $43-82$.

Dharmapala, D. and Hines, J.R. (2009), "Which countries become tax havens?", Journal of Public Economics, Vol. 93 Nos 9/10, pp. 1058-1068.

di Giovanni, J. and Levchenko, A.A. (2009), “Trade openness and volatility”, Review of Economics and Statistics, Vol. 91 No. 3, pp. 558-585.

Diamond, W.H. and Diamond, D.B. (2002), Tax Havens of the World, Matthew Bender Books, Newark, NJ.

Ebeke, C.H. (2014), "Do international remittances affect the level and the volatility of government tax revenue?", Journal of International Development, Vol. 26 No. 7, pp. 1039-1053.

Ebeke, C. and Ehrhart, H. (2012), "Tax revenue instability in Sub-Saharan Africa: Consequences and remedies", Journal of African Economies, Vol. 21 No. 1, pp. 1-27.

Ehrhart, H. (2011), "Assessing the relationship between democracy and domestic taxes in developing countries", Economics Bulletin, Vol. 32 No. 1, pp. 551-566.

Figlio, D.N. and Blonigen, B.A. (2000), “The effects of foreign direct investment on local communities”, Journal of Urban Economics, Vol. 48 No. 2, pp. 338-363.

Fuest, C., Hebous, S. and Riedel, N. (2011), "International debt shifting and multinational firms in developing economies", Economics Letters, Vol. 113 No. 2, pp. 135-138.

Fuest, C. and Riedel, N. (2009), "Tax evasion, tax avoidance and tax expenditures in developing countries: a review of the literature", Report Prepared for the UK Department for International Development (DFID), 1-69.

Gajigo, O. and Mutambatsere, E. and Ndiaye, G. (2012), "Gold mining in Africa: maximizing economic returns for countries", Working Paper 147, African Development Bank, Tunis.

Gnangnon, S.K. and Brun, J.F. (2019), "Tax reform and public revenue instability in developing countries: Does the volatility of development aid matter?", Journal of International Development, Vol. 31 No. 8, pp. 764-785. 
Gnangnon, S.K. (2017), "Impact of foreign direct investment (FDI) inflows on non-resource tax and corporate tax revenue", Economics Bulletin, Vol. 37 No. 4, pp. 2890-2904.

Gnangnon, S.K. (2020), "General budget support and tax revenue instability in developing countries", International Economic Journal, Vol. 34 No. 3, pp. 405-425.

Gong, L. and Zou, H.-F. (2002), "Effects of growth and volatility in public expenditures on economic growth: Theory and evidence", Annals of Economics and Finance, Vol. 3 No. 2, pp. 379-406.

Gropp, R. and Kostial, K. (2001), "FDI and corporate tax revenue: Tax harmonization or competition?”, Finance and Development, Vol. 38 No. 2, pp. 10-10.

Gropp, R. and Kostial, K. (2000), "The disappearing tax base: is foreign direct investment eroding corporate income taxes?”, IMF Working Paper, No 00/173, Washington, DC, pp. 1-39.

Guerin, S.S. and Manzocchi, S. (2009), "Political regime and FDI from advanced to emerging countries", Review of World Economics, Vol. 145 No. 1, pp. 75-91.

Haddad, M., Lim, J.J., Pancaro, C. and Saborowski, C. (2013), “Trade openness reduces growth volatility when countries are well diversified", Canadian Journal of Economics/Revue Canadienne D'économique, Vol. 46 No. 2, pp. 765-790.

Hebous, S., Ruf, M. and Weichenrieder, A.J. (2011), "The effects of taxation on the location decision of multinational firms: M\&A versus greenfield investments”, National Tax Journal, Vol. 64 No. 3, pp. 817-838.

Herzer, D. (2011), "The long-run relationship between outward FDI and total factor productivity: Evidence for developing countries", Journal of Development Studies, Vol. 47 No. 5, pp. 767-785.

Hines, J.R., Jr and Rice, E.M. (1994), "Fiscal paradise: foreign tax havens and American business", The Quarterly Journal of Economics, Vol. 109 No. 1, pp. 149-182.

Huizinga, H. and Laeven, L. (2008), "International profit shifting within multinationals: a multi-country perspective", Journal of Public Economics, Vol. 92 Nos 5/6, pp. 1164-1182.

Isham, J., Pritchett, L., Woolcock, M. and Busby, G. (2005), "The varieties of resource experience: natural resource export structures and the political economy of economic growth", The World Bank Economic Review, Vol. 19 No. 2, pp. 141-174.

Janský, P. and Palanský, M. (2019), "Estimating the scale of profit shifting and tax revenue losses related to foreign direct investment", International Tax and Public Finance, Vol. 26 No. 5, pp. 1048-1103.

Jensen, N.M. (2003), "Democratic governance and multinational corporations: political regimes and inflows of foreign direct investment", International Organization, Vol. 57 No. 3, pp. 587-616.

Kim, D.-H., Lin, S.-C. and Suen, Y.-B. (2016), “Trade, growth and growth volatility: new panel evidence”, International Review of Economics and Finance, Vol. 45, pp. 384-399.

Konara, P. and Wei, Y. (2017), "Foreign direct investment as a catalyst for domestic firm development: the case of Sri Lanka", Transnational Corporations, Vol. 23 No. 3, pp. 1-32.

Kose, M.A., Prasad, E.S. and Terrones, M.E. (2006), "How do trade and financial integration affect the relationship between growth and volatility?”, Journal of International Economics, Vol. 69 No. 1, pp. 176-202.

Lensink, R. and Morrissey, O. (2006), "Foreign direct investment: flows, volatility, and the impact on growth", Review of International Economics, Vol. 14 No. 3, pp. 478-493.

Li, Q. and Resnick, A. (2003), "Reversal of fortunes: Democratic institutions and foreign direct investment inflows to developing countries", International Organization, Vol. 57 No. 1, pp. 175-211.

Lim, D. (1983), "Instability of government revenue and expenditure in less developed countries", World Development, Vol. 11 No. 5, pp. 447-450.

Marshall, M.G., Gurr, T.R. and Jaggers, K. (2018), Polity IV Project: Political Regime Characteristics and Transitions, 1800-2017, Centre for Systemic Peace, Vienna, VA. 
AEA

29,86

Mavrotas, G., Murshed, S.M. and Torres, S. (2011), "Natural resource dependence and economic performance in the 1970-2000 period”, Review of Development Economics, Vol. 15 No. 1, pp. 124-138.

Meller, B. (2013), “The two-sided effect of financial globalization on output volatility”, Review of World Economics, Vol. 149 No. 3, pp. 477-504.

Mendoza, E. (1991), "Real business cycles in a small open economy", American Economic Review, Vol. 81, pp. 797-818.

Mireku, K., Animah, E.A. and Domeher, D. (2017), "Trade openness and economic growth volatility: an empirical investigation", Cogent Economics and Finance, Vol. 5 No. 1, pp. 1385438.

Mutti, J. and Gruber, H. (2004), "Empirical asymmetries in foreign direct investment and taxation", Journal of International Economics, Vol. 62 No. 2, pp. 337-358.

Nagel, K., Herzer, D. and Nunnenkamp, P. (2015), “How does FDI affect health?”, International Economic Journal, Vol. 29 No. 4, pp. 655-679.

Nguyen, H.T.T., Nguyen, M.H. and Goenka, A. (2014), How Does FDI Affect Corporate Tax Revenue of the Host Country, Document De Recherche Epee, Centre D'Eudes Des Politiques Economiques De L'universite D'evry, Retrieved August 10, 13-03.

Nickell, S. (1981), "Biases in dynamic models with fixed effects", Econometrica, Vol. 49 No. 6, pp. 1417-1426.

OECD (2017), "OECD transfer pricing guidelines for multinational enterprises and tax administrations 2017", (accessed 7 June 2018), doi: 10.1787/tpg-2017-en.

Okey, M. and Nézan, K. (2013), "Tax revenue effect of foreign direct investment in West Africa", African Journal of Economic and Sustainable Development, Vol. 2 No. 1, pp. 1-22.

Oneal, J.R. (1994), "The affinity of foreign investors for authoritarian regimes", Political Research Quarterly, Vol. 47 No. 3, pp. 565-588.

Peralta, S., Wauthy, X. and Van Ypersele, T. (2006), "Should countries control international profit shifting?", Journal of International Economics, Vol. 68 No. 1, pp. 24-37.

Raff, H. and Srinivasan, K. (1998), "Tax incentives for Import-Substituting foreign investment: does signaling play a role?", Journal of Public Economics, Vol. 67 No. 2, pp. 167-193.

Razin, A., Sadka, E. and Coury, T. (2003), "Trade openness, investment instability and terms-of-trade volatility", Journal of International Economics, Vol. 61 No. 2, pp. 285-306.

Rodrik, D. (1996), "Understanding economic policy reform”, Journal of Economic Literature, Vol. 34 No. 1, pp. 9-41.

Roodman, D.M. (2009), "A note on the theme of too many instruments", Oxford Bulletin of Economics and Statistics, Vol. 71 No. 1, pp. 135-158.

Seabrooke, L. and Wigan, D. (2015), "How activists use benchmarks: reformist and revolutionary benchmarks for global economic justice", Review of International Studies, Vol. 41 No. 5, pp. 887-904.

Shirodkar, V. and Konara, P. (2017), "Institutional distance and foreign subsidiary performance in emerging markets: moderating effects of ownership strategy and host country experience", Management International Review, Vol. 57 No. 2, pp. 179-207.

Stevens, P. and Dietsche, E. (2008), "Resource curse: an analysis of causes, experiences and possible ways forward", Energy Policy, Vol. 36 No. 1, pp. 56-65.

Sung, H.-E. (2004), "Democracy and political corruption: a cross-national comparison", Crime, Law and Social Change, Vol. 41 No. 2, pp. 179-193.

Swenson, D.L. (2001), "Transaction type and the effect of taxes on the distribution of foreign direct investment in the United States", in Hines, J. J. (Ed.), International Taxation and Multinational Activity, University of Chicago Press, pp. 89-112. 
Taylor, G., Richardson, G. and Lanis, R. (2015), "Multinationality, tax havens, intangible assets, and transfer pricing aggressiveness: an empirical analysis", Journal of International Accounting Research, Vol. 14 No. 1, pp. 25-57.

Yeyati, E.L., Panizza, U. and Stein, E. (2007), “The cyclical nature of North-South FDI flows", Journal of International Money and Finance, Vol. 26 No. 1, pp. 104-130.

Zee, H.H., Stotsky, J.G. and Ley, E. (2002), "Tax incentives for business investment: a primer for policy makers in developing countries", World Development, Vol. 30 No. 9, pp. 1497-1516.

\section{Further reading}

Crivelli, E., de Mooij, R. and Keen, M. (2016), "Base erosion profit shifting and developing countries", FinanzArchiv, Vol. 72 No. 3, pp. 268-301.

De Mooij, R.A. and Ederveen, S. (2003), "Taxation and foreign direct investment: a synthesis of empirical research", International Tax and Public Finance, Vol. 10 No. 6, pp. 673-693. 
AEA

29,86

148

\section{Appendix 1}

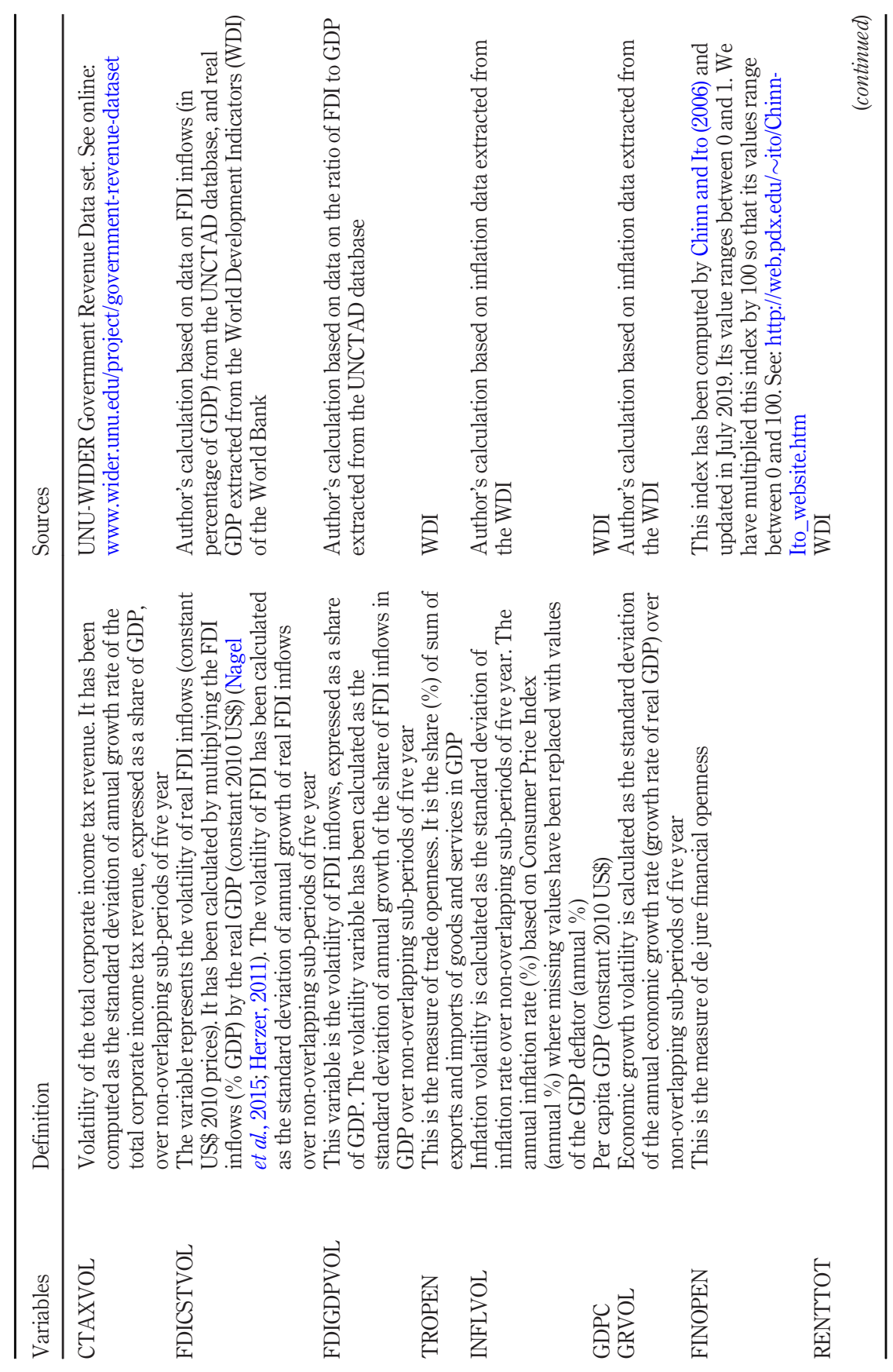

Table A1.

Definition and source of variables 
Volatility of foreign direct investment

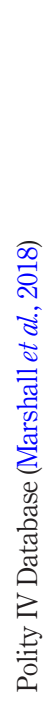

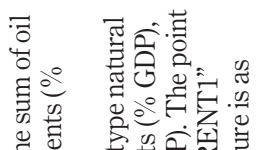

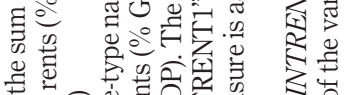

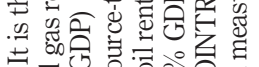

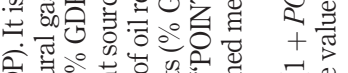



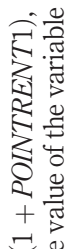

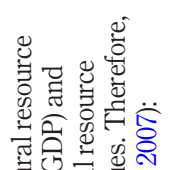
嵌 总

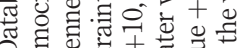

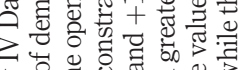

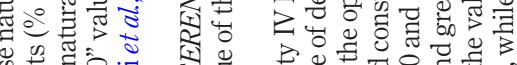

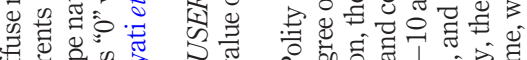

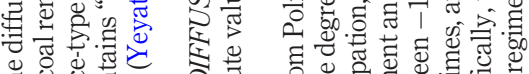

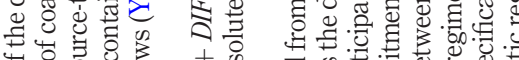
넝 完 + 员

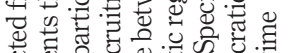
宩节它 कै

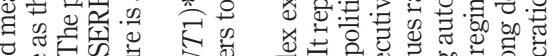

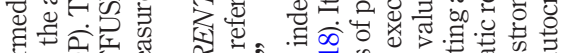

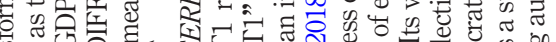

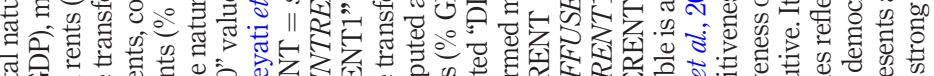

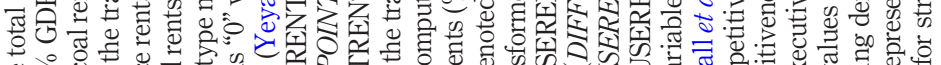

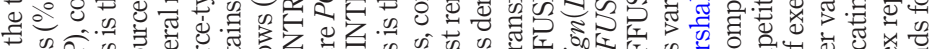

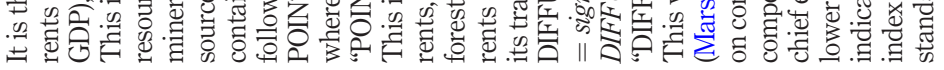

点

ڤ્ટે 
AEA

29,86

150

\section{Appendix 2}

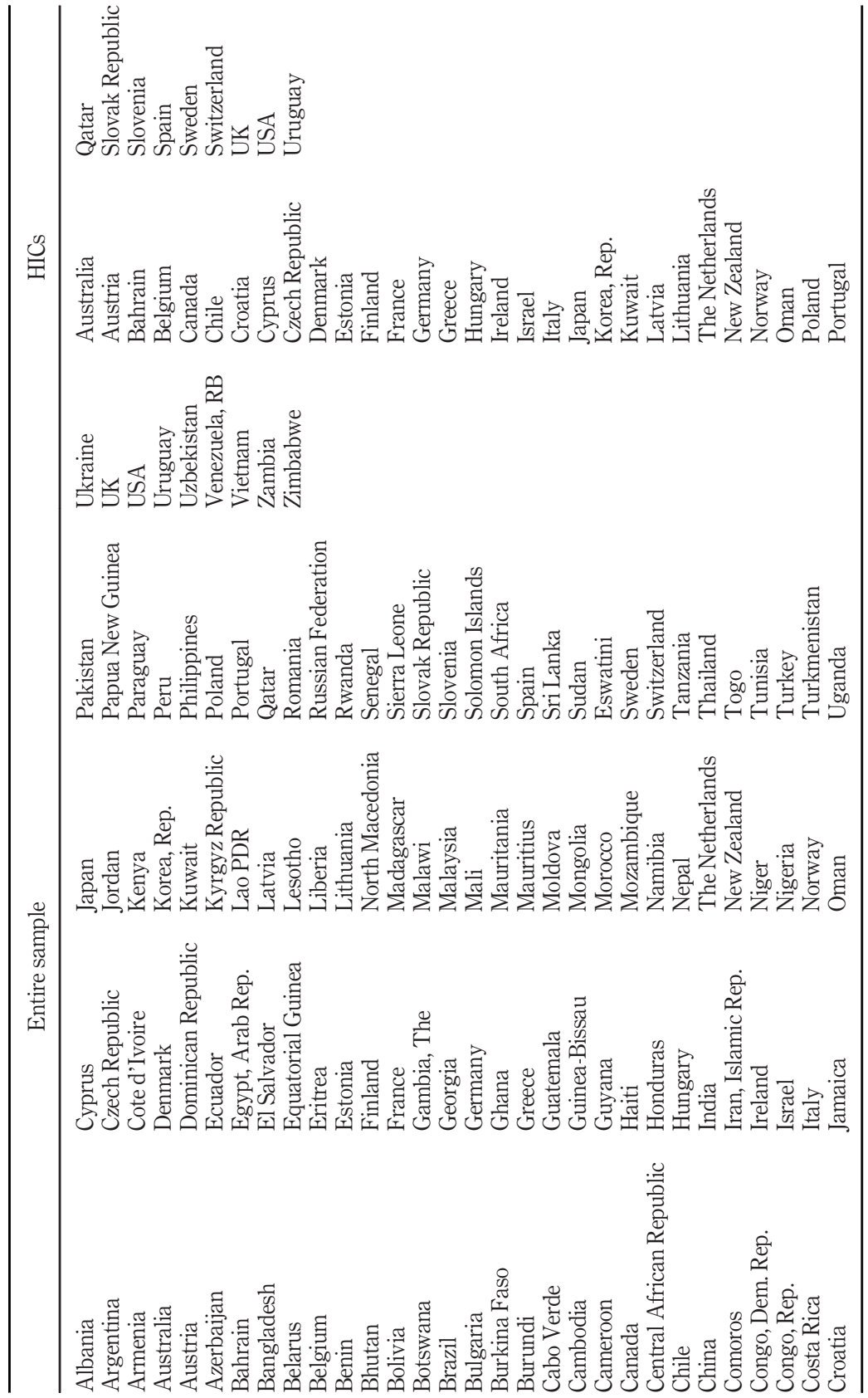

Table A2.

List of countries contained in the entire sample 


\begin{tabular}{|c|c|c|c|c|c|c|}
\hline Variable & Observations & Mean & Standard deviation & Minimum & Maximum & \\
\hline CTAXVOL & 621 & 0.2616569 & 0.4109418 & 0.000247 & 6.754 & 151 \\
\hline FDICSTVOL & 621 & 10.781 & 98.676 & 0.054 & 2063.885 & \\
\hline FDIGDPVOL & 610 & 10.809 & 105.788 & 0.053 & 2370.18 & \\
\hline RENTTOT & 621 & 5.847 & 8.763 & 0.0027 & 62.895 & \\
\hline POINTRENT & 621 & 3.596 & 7.944 & 0 & 62.894 & \\
\hline DIFFUSERENT & 621 & 2.253 & 4.038 & 0 & 27.953 & \\
\hline GRVOL & 621 & 3.006 & 2.894 & 0.143 & 30.798 & \\
\hline TROPEN & 621 & 74.982 & 36.148 & 13.795 & 235.669 & \\
\hline FINOPEN & 621 & 51.875 & 35.77902 & 0 & 100 & \\
\hline POLITY2 & 621 & 4.423 & 6.312 & -10 & 10 & Table A3. \\
\hline INFLVOL & 621 & 25.222 & 392.843 & 0.144 & 9730.51 & Descriptive statistics \\
\hline GDPC & 621 & 13230.74 & 17179.65 & 173.42 & 89690.41 & on variables \\
\hline
\end{tabular}

\section{Corresponding author}

Sena Kimm Gnangnon can be contacted at: kgnangnon@yahoo.fr

For instructions on how to order reprints of this article, please visit our website: 